\title{
Overall Estimation of Anti-Oxidant Activity by Mammal Macrophage
}

\author{
Nobuo Yamaguchi ${ }^{1,2}$, Natsuko Kawada ${ }^{2}$, Xinfeng $\mathrm{Jia}^{3}$, Kazuhiro Okamoto ${ }^{4}$, Katsuko Okuzumi ${ }^{5}$, \\ Rui Chen ${ }^{3}$, Takashi Takahashi ${ }^{5}$ \\ ${ }^{1}$ Department of Fundamental Research for CAM, Kanazawa Medical University, Ishikawa, Japan; ${ }^{2}$ Ishikawa Natural Medicinal \\ Products Research Center, Kanazawa, Japan; ${ }^{3}$ Union Hospital, Tongji Medical College, Huazhong University of Science and Tech- \\ nology, Wuhan, China; ${ }^{4}$ Kanazawa University Graduate School of Medical Science, Kanazawa, Japan; ${ }^{5}$ Laboratory of Infectious \\ Diseases, Graduate School of Infection Control Sciences, Kitasato University, Tokyo, Japan. \\ Email: serumaya@kanazawa-med.ac.jp
}

Received November $11^{\text {th }}, 2013$; revised December $11^{\text {th }}, 2013$; accepted December $20^{\text {th }}, 2013$

Copyright (C) 2014 Nobuo Yamaguchi et al. This is an open access article distributed under the Creative Commons Attribution License, which permits unrestricted use, distribution, and reproduction in any medium, provided the original work is properly cited. In accordance of the Creative Commons Attribution License all Copyrights (C) 2014 are reserved for SCIRP and the owner of the intellectual property Nobuo Yamaguchi et al. All Copyright (C) 2014 are guarded by law and by SCIRP as a guardian.

\section{ABSTRACT}

Super oxide anion had been known as a critical role in a phagocytic cell when microorganisms invade inside. However, this radical seldom need for a clean environment such in a developed country. Moreover, this agent sometimes triggered as serious factor in the site of inflammation. There are many papers which concerned newly found anti-oxidative substances. However, many reports only focused on the molecular basis in vitro, how oxidative stress damaged the human tissue. The key factor for oxidative stress needs to be discussed first for immunological standpoint, such as armed reduction treaty. In other words, minimum armed force is necessary for an invasion by outer or inner irregular cells. On the basis of phagocytic function of the cell in vivo, we tried to access anti-oxidative activity by employing peritoneal murine macrophage and human monocyte. So, the purpose of this study is to establish a conventional but tailor made system for which is useful for evaluating the anti-oxidative activity to different constition. Especially in human peripheral monocyte, the sample was tested each constitution such in granulocyte rich type and lymphocyte rich typ. In order to establish the direct estimation by phagocytic cell, a murine peritoneal exudates cell suspension was obtained after one week of oral administration with anti-oxidative sample. The samples we selected were traditional Chinese medicine, Shi-Quan-Da-Bu-Tang (SDT), Bu-Zong-Ye-Qi-Tang (BYT) and Shao-Chin-Rong-Tang sCRT), Agaricus, Chlorella, and Propolis. The amount of generated super oxide anion was calculated through measuring the optical density change of this supernatant using cytochrome-C which was reduced by generated super oxide anion in the phagocytic cell. The generated super oxide anion after administration of Agaricus, Chlorella, SDT, BYT, sCRT and Propolis were 2.64, 1.95, 1.24, 1.25, 2.88, $2.55 \times 10^{-5} \mathrm{mmol} / \mathrm{ml}$, respectively, whereas $2.85 \times 10^{-5} \mathrm{mmol} / \mathrm{ml}$ in control group. The fermented sample from SDT, BYT, sCRT and microfied Propolis were also tested and the value of super oxide anion were $0.62,0.84,1.50$ and $2.55 \times 10^{-5} \mathrm{mmol} / \mathrm{ml}$, respectively. In this report, we discussed the direct method for measuring the generated super oxide anion of macrophages, especially from different constitution.

\section{KEYWORDS}

Anti-Oxidant Sample; Super Oxide Anion; Neutrophil; Macrophage; Cytochrome-c; Constitution

\section{Introduction}

The first line of defense system is phagocytic cell both innate and adoptive immune system in mammal [1-5]. In a lower animal, even in invertebrate one, the first and the last line of defense is also phagocytic cell. So the phago- cytic cell is an essential to maintain the physiological system for surviving a conventional circumstance [6-10]. In such cell, super oxide anion had been known as critical role in a phagocytic cell when microorganisms invaded inside [11-15]. But, this anion seldom need for a 
clean environment such in a developed country. Moreover, this agent sometimes triggered as a serious factor in the site of inflammation. There are many papers which concerned newly found anti-oxdants [16-26]. However, many reports only discussed with the molecular mechanism in vitro, how oxidative stress damaged the human tissue. The key factors for oxidative stress have to be discuses first for immunological standpoint, so called armed reduction treaty. In other words, a minimum armed force is necessary for an invasion by outer or inner iregular cells. On the basis of phagocytic cell, this report aimed to select anti-oxidative sample and tried to show a more suitable system to select the anti-oxidative selection of the sample. For above stand point, we tried to estimate anti-oxidative activity by employing peritoneal murine macrophage. The purpose of this study is to establish a conventional method for which is useful for evaluating the antioxidant activity directory with macrophage. Oxidative stress is an important process that occurs in vivo during aging and is considered one of the main causes of molecular damage to cellular and tissue structures. These changes can accumulate in biological structures during aging.

With aging there is an increase of oxidative stress due to an imbalance between the oxidant production and the antioxidant levels. Since immune cell functions are especially linked to free radical generation, the oxidant and antioxidant balance is essential for these cells. Although low levels of antioxidants cause a decrease in immune system, high levels of antioxidants could damage the tissues [27-36].

In this communication, we further assessed by different constitution in human namely granulocyte-rich type (G-type) and lymphocyte-rich type (L-type). Since Abo reported that there were at least two different type concerning with the ratio of leukocyte subsets, granulocyte and lymphocytes. He reported that G-rich type was over $60 \%$ of granulocyte in peripheral blood and over $40 \%$ of lymphocyte was L-type [37-40]. So we tried to test the anti-oxidative sample for the different type of constitution whether the sample mainly affect for g-rich type or not?

In this report, Agaricus, Chlorella, herbal medicine (Kampoh), Shi-Quan-Da-Bu-Tang (SDT), Bu-Zong-YeQi-Tang (BYT) and Shao-Chin-Rong-Tang sCRT), and Propolis are orally administered to mice. After one week, the amount of super oxide anion were assessed and tried to overall evaluation for human monocyte from different constitution of volunteers.

\section{Subjects and Methods}

\subsection{Animals}

Eight weeks old female BALB/c and C57BL/6NCrj were purchased from Sankyo Laboratory Service Corporation
(Shizuoka, Japan). All mice were kept under specific pathogen-free conditions. The water and food were freely accessed by each animal.

\subsection{Human Peripheral Monocytes}

\section{Subjects}

We found 10 healthy volunteers (mean age, $41 \pm 15.2$ years) and informed consented according to The Ethics Committee of Kanazawa Medical University.

In addition, the experimental group was further divided into two groups according to the variation after hydrotherapy.

The whole blood obtained from the subjects by blood collection tube containing an anticoagulant EDTA-2K. (Becton Dickinson) as a secondary antibody and were incubated for 90 minutes at $4^{\circ} \mathrm{C}$. After washing with PBS, + FCS, the grass adherent cells were added after washing with PBS and served for the processing described in Section 2.5 (Figure 1).

\subsection{Reagents}

As for the basic medium, HEPES buffer (HEPES 17 $\mathrm{mM}, \mathrm{NaCl} 120 \mathrm{mM}$, Glucose $5 \mathrm{mM}, \mathrm{KCl} 5 \mathrm{mM}, \mathrm{CaCl}_{2} 1$ $\mathrm{mM}, \mathrm{MgCl}_{2} 1 \mathrm{mM}$ ) was prepared and sterilized by filtration. Phrbol 12-myristate 13-acetate (PMA, Sigma, USA) was diluted to $10^{-6} \mathrm{M}$ by dimethylsulfoxide (DMSO, Sigma, USA) and used as a stimulant for super oxide anion generation of murine peritoneal exudative cells. Cytochrome-c (Sigma, USA) was diluted to $1 \mathrm{mM}$ by HEPES buffer. Since cytochrome-c reduced by super oxide showed maximum absorbance at $550 \mathrm{~nm}$, we used cytochrome-c to measure the amount of super oxide anion generation through spectrophotometrical technique.

Oyster Glycogen (type II, Sigma, USA) was diluted in the purified water ( $10 \% \mathrm{w} / \mathrm{v}$, Wako, Japan) and autoclaved at $120^{\circ} \mathrm{C}$ for $20 \mathrm{~min}$. This solution was used for intraperitoneal injection to mice in order to induce peripheral neutrophils into the abdominal cavity.

\subsection{Anti-Oxidative Sample}

Agaricus was purchased from Ohbiken Co. Ltd (Yamanashi, Japan), Chlorella was purchased from Taiwan Chlorella Co. Ltd (Taipei, Taiwan) and Propolis was purchased from Epimedix Co. Ltd (Kanazawa, Japan). Traditional herbal medicine, Shi-Quan-Da-Bu-Tang (SDT), Bu-Zong-Ye-Qi-Tang (BYT) and Shao-Chin-Rong-Tang sCRT), were purchased from Tochimoto-Tenkaidoh Co. Ltd (Osaka, Japan) and fermented at the same company. Propolis was microfied at Futaba Co. Ltd (Shizuoka, Japan) by using mechanical crush system. Both microfied and not microfied Propolis, i.e. native Propolis were solublized in water, so we used $10 \%$ DMSO as a 
Preparation of Peritoneal Exudate Cell
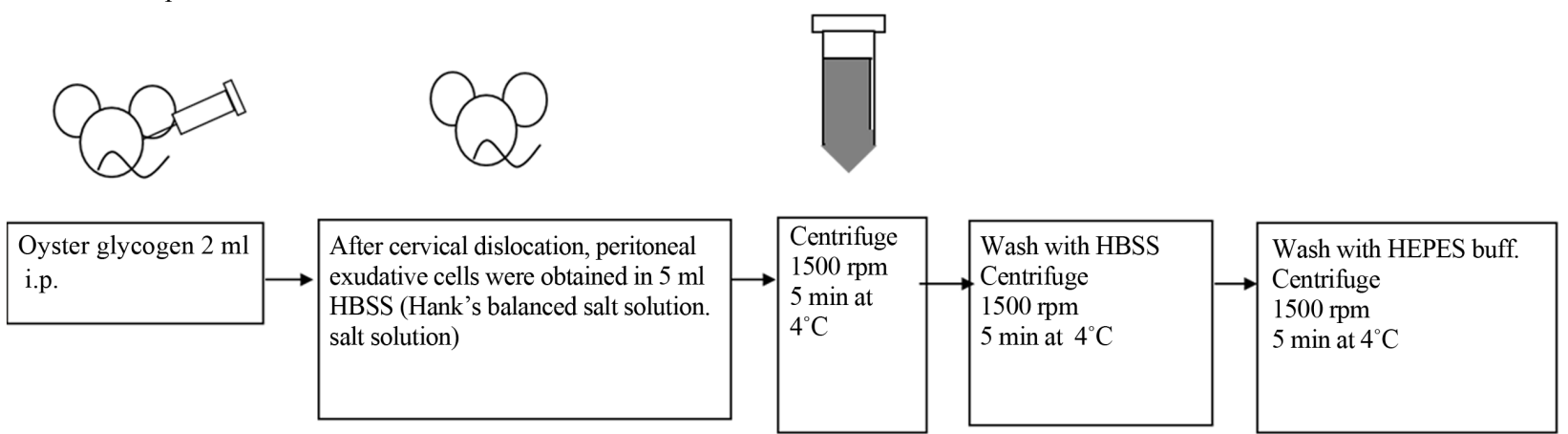

Measurement of generated super oxide

1 HEPES buf. $0.9 \mathrm{ml}$
2 Cytc $100 \mu \mathrm{l}$
3 Cell suspension $100 \mu \mathrm{l}$
(prepared to $5 \times 10^{6}$ cells $/ \mathrm{ml}$ )
4 PMA $10 \mu \mathrm{l}$
Incubate at $37^{\circ} \mathrm{C}$ for $20 \mathrm{~min}$

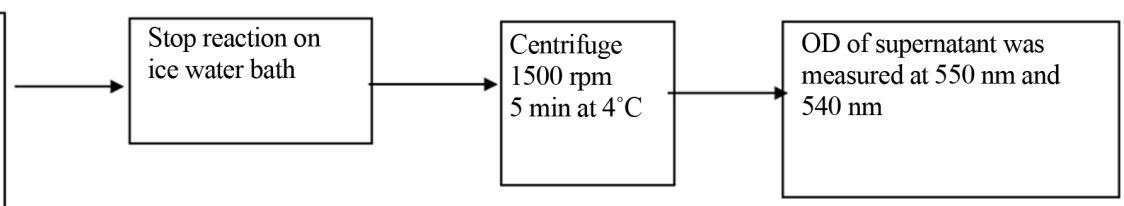

Figure 1. Experimental design.

solvent.

Red and white wines were aspirated overnight at room temperature in order to eliminate alcohol.

\subsection{A Measuring the Amount of Super Oxide Anion Generated by Murine Peritoneal Macrophage and Human Peripheral Monocytes}

Each sample was orally administered to mice $(500 \mathrm{mg} / \mathrm{kg}$ ) for one week. Two $\mathrm{ml}$ of $10 \%$ Oyster glycogen was injected intraperitonealy about 10 hours before the assay. Sufficient murine peritoneal exudate cells were induced ten hours after the stimulation (data not shown). Mice were euthanized by cervical dislocation, murine peritoneal exudate cells (PEC) suspension was centrifuged twice for 5 minutes at $1500 \mathrm{rpm}, 4^{\circ} \mathrm{C}$. Then PEC were prepared to $1 \times 10^{6}$ cells $/ \mathrm{ml}$ of HEPES buffer. One hundred $\mu \mathrm{l}$ cytochrome-c and $10 \mu \mathrm{l}$ PMA were added to the cell suspension and this was incubated for 20 minutes at $37^{\circ} \mathrm{C}$. The reaction mixture was then centrifuged for 10 minutes at $1500 \mathrm{rpm}, 4^{\circ} \mathrm{C}$. OD of supernatant was measured at both $550 \mathrm{~nm}$ and $540 \mathrm{~nm}$, the amount of generated super oxide anion was shown in the formula; increased absorbance at $550 \mathrm{~nm}\left(\triangle \mathrm{A}_{550-540}\right) / 19.1 \times 10^{3}$ $(\mathrm{mmol} / \mathrm{ml})$.

In order to ensure if we really measured the amount of generated super oxide anion or not, we tried to add super oxide anion dismutase (SOD), famous enzyme for its anti-oxidative effect [21-23], into our experimental system. The result was as expected that the reduction of cytochrome-c was inhibited just after addition of SOD. This showed us that our experimental system could be used properly for measuring the amount of generated super oxide anion.

\subsection{Statistical Analysis}

The statistical comparisons between two groups (before and after hot-spring hydrotherapy) for the test of significant difference were performed using paired t-test and wilcoxon signed-ranks test. Further, the test of the correlation were performed a spearman's correlation coefficient by rank test. Data are expressed as means \pm standard error of mean (SE). A $P$ value $<0.05$ was considered to be statistically significant.

Data are expressed as means \pm standard deviations. The differences between HF-treated and non-treated conditions were compared using a one-tailed analysis of variance. A $P$ value $<0.05$ was considered to be statistically significant.

\section{Results}

\subsection{The Amount of Generated Super Oxide Anion}

The experimental animals were orally administered by each sample for $500 \mathrm{mg}$ by a stomach tube. The perito- 
neal excaudate cell were collected 5 days after injection with oyster glycogen. The cell sample consisted with $92 \%$ in macrophages. The collected cell were treated by the method described in the section 2.5. The amount of generated super oxide anion was calculated in the formula shown in the section 2.5. At first, we compared the all the sample that we prepared. The generated super oxide anion after one week administration of Agaricus and Chlorella were 2.64 and $1.95 \times 10^{-5} \mathrm{mmol} / \mathrm{ml}$, respectively, whereas $2.85 \times 10^{-5} \mathrm{mmol} / \mathrm{ml}$ in control group. The generated super oxide anion after one week administration of herbal medicine Shi-Quan-Da-Bu-Tang (SDT), Bu-Zong-Ye-Qi-Tang (BYT) and Shao-Chin-Rong-Tang (sCRT) were 1.24, 1.25 and $2.88 \times 10^{-5} \mathrm{mmol} / \mathrm{ml}$, respectively. The generated super oxide anion after one week administration of Propolis was $2.55 \times 10^{-5} \mathrm{mmol} /$ $\mathrm{ml}$.

Within these samples, TCM harbs showed excellent effect on th anti-oxidative effect except for sCRT, decreased super oxide anion generation after one week administration in mice (Figure 2).

\subsection{The Comparison of Generated Super Oxide Anion between the Fermented and Non-Fermented TCM herbs}

Traditional Chinese Medicine is one of the possible materials for regulating anti-oxidative activity. We tried to compare the TCM herbs with or without treatment by yeast/fermentation. For the use of TCM herbs usually extract only by hot water extraction. All the strained usually dumped without further useage. In order to utilize the whole components of herbal material, we asked yeast cells to cut down into a small molecule, stop to the step before making alcohol/wine. Since the anti-oxidative effects of herbal medicine were demonstrated, we investigated the way to reinforce this effect. The fermentation is one of the possibilities. Since the fermentation is processed by bacterial digestion and degradation, less of the efficient constituents would be lost than commonly used extraction by hot water. Therefore we decided to ferment the herbal medicine by yeast (Saccharomyces cerevisiae), expecting the enhancement of its anti-oxidative effects.

Generated super oxide

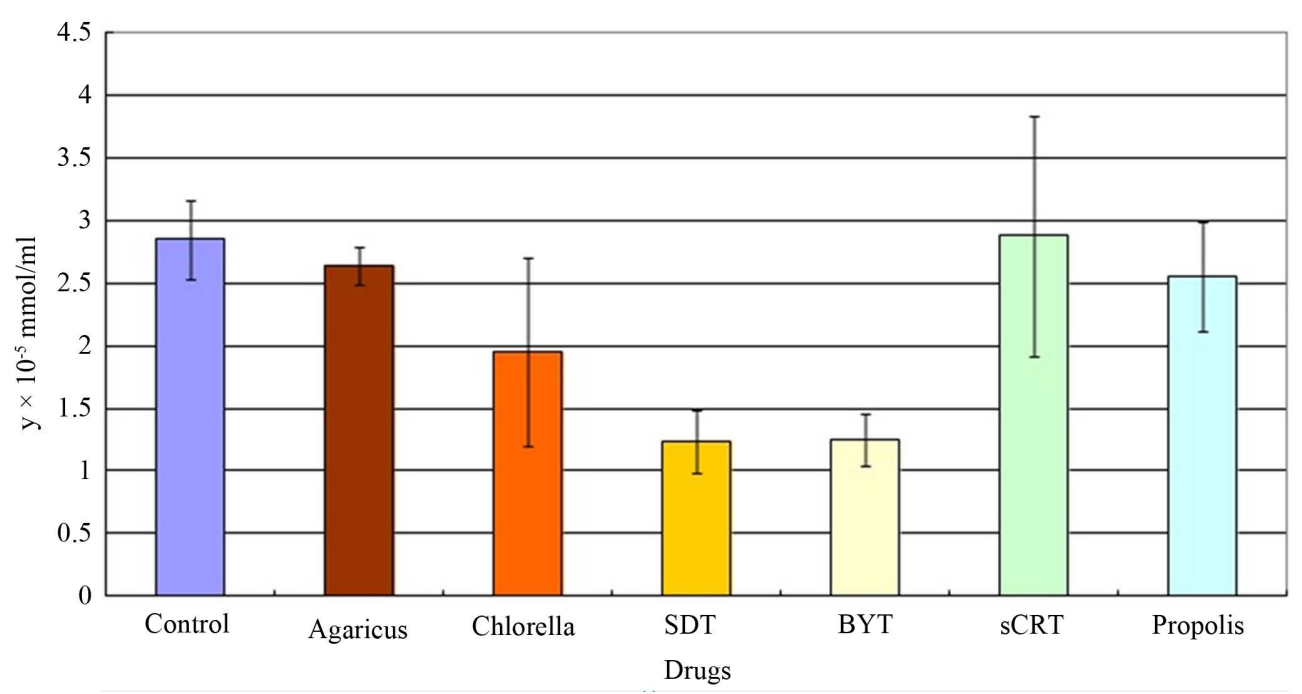

\begin{tabular}{|l|c|}
\hline Drugs & Generated $\mathrm{O}_{2}^{-}\left(\times 10^{-5} \mathrm{mmol} / \mathrm{ml}\right)$ \\
\hline Agaricus burazei & 2.64 \\
Chlorella pirenoidosa & 1.95 \\
SDT & 1.24 \\
BYT & 1.25 \\
sCRT & 2.88 \\
Propolis & 2.55 \\
Control & 2.85 \\
\hline
\end{tabular}

Figure 2. Super oxide anion dismutase (SOD) inhibited reduction of cytochrome-c SOD was diluted to $1 \mathrm{mg} / \mathrm{ml}$ by HEPES buffer. Thirty $\mu$ l of SOD was added to the reaction mixuture 3, 5 and 10 minutes after incubation began. The reduction of cytochrome-c was inhibited just after adding of SOD. 
The generated super oxide anion after one week administration of fermented herbal medicine Shi-Quan-DaBu-Tang (SDT), Bu-Zong-Ye-Qi-Tang (BYT) and ShaoChin-Rong-Tang (sCRT) were $0.62,0.84$ and $1.50 \times 10^{-5}$ $\mathrm{mmol} / \mathrm{ml}$, respectively. All the fermented herbal medicine decreased super oxide anion generation in compare with each of non- fermented one (Figure 3).

\subsection{The Comparison of Generated Super Oxide Anion between the Microfied and Normal Propolis}

The antioxidative activity of Propolis was demonstrated, however the particle of native Propolis was seen to be quite gross. In order to reinforce its antioxidative activity from physical constructive view point, we tried to microfied Propolis in $0.5 \mu \mathrm{m}$, expecting enlarged attachment area with reaction mixture.

The generated super oxide anion after one week administration of microfied Propolis was $2.52 \times 10^{-5} \mathrm{mmol} /$ $\mathrm{ml}$, whereas not microfied Propolis was $2.55 \times 10^{-5}$ $\mathrm{mmol} / \mathrm{ml}$. The antioxidative activity was the same level compared by microfying sample (Figure 4).

\subsection{Constitution Dependent Effect on Human Monocyte}

The trial was designed to test for human monocyte derived from deferent constitution, G-rich type and L-rich type. Each sample was administered for 5 time in a week, Two weeks after the cooling down, the next sample was tested to the same volunteer (Tables 1 and 2). In this way, four sample were accessed by the same group of human subject. The results were shown in Table 3 . In case of murine macrophage, fermented TCM were effective to regulate super oxide anion. Furthermore, G-type was much regulate anti oxidative effect than L-type of monocyte, indicting neat regulation for different constitution (Table 3).

\section{Discussion}

Reactive oxygen species released by activated polymorphonuclear leukocyte as an expression of their definitive function are considered to be major source of cytotoxic oxidative stress. Since oxygen free radicals cause DNA damage and this may lead to gene modifications, reactive oxygen might be carcinogenic. Therefore oxidative stress

Generated super oxide

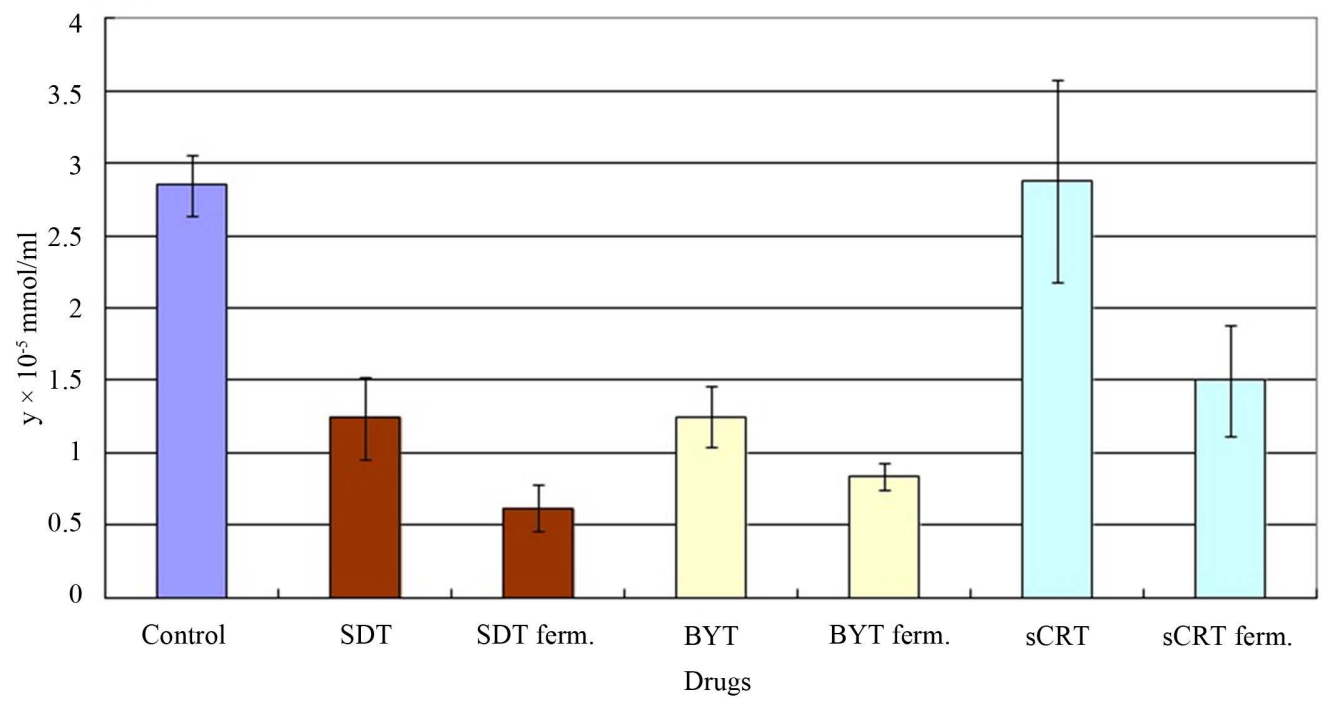

\begin{tabular}{|l|c|}
\hline Drugs & Generated $\mathrm{O}_{2}^{-}\left(\times 10^{-5} \mathrm{mmol} / \mathrm{ml}\right)$ \\
\hline fermented SDT & 0.62 \\
fermented BYT & 0.84 \\
fermented sCRT & 1.50 \\
micrified Propolis & 2.52 \\
Cont & 2.85 \\
\hline
\end{tabular}

Figure 3. Amount of generated super oxide anion after one week administration of Shi-Quan-Da-Bu-Tang (SDT), BuZong-Ye-Qi-Tang (BYT) and Propolis. 
Generated super oxide

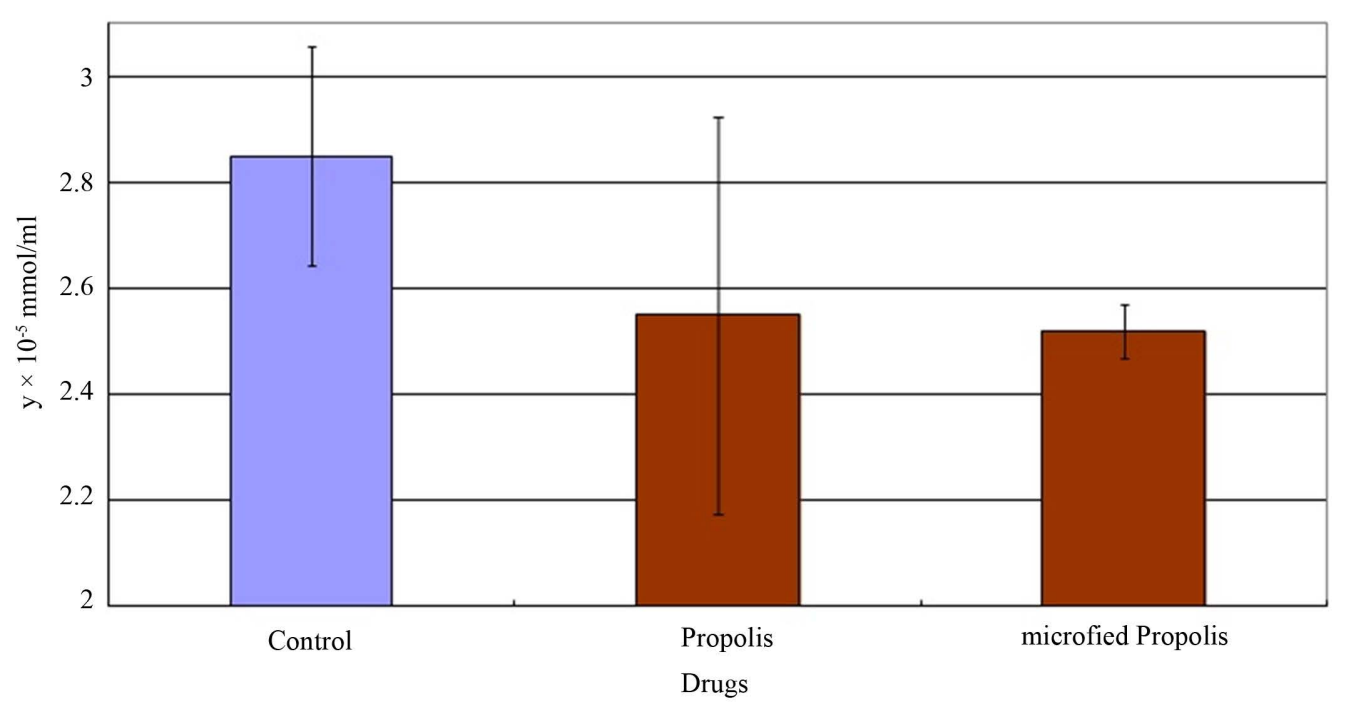

Figure 4. Fermentation decreased the generation of super oxide anion Amount of generated super oxide anion after one week administration of herbal medicine Shi-Quan-Da-Bu-Tang (SDT), Bu-Zong-Ye-Qi-Tang (BYT) and its fermented one.

Table 1. Amount of generated super oxide anion after one week oral administration of Shi-Quan-Da-Bu-Tang (SDT), Bu-Zong-Ye-Qi-Tang (BYT) and Propolis.

\begin{tabular}{|c|c|}
\hline Samples & Generated $\mathrm{O}_{2}^{-} \quad\left(\times 10^{-5} \mathrm{mmol} / \mathrm{ml}\right)$ \\
\hline Agaricus burazei & 2.64 \\
\hline Chlorella pirenoidosa & 1.95 \\
\hline SDT & 1.24 \\
\hline BYT & 1.25 \\
\hline sCRT & 2.88 \\
\hline Propolis & 2.55 \\
\hline Control & 2.85 \\
\hline
\end{tabular}

Table 2. Amount of generated super oxide anion after one week oral administration of fermented Shi-Quan-Da-BuTang (SDT), Bu-Zong-Ye-Qi-Tang (BYT), and microfied Propolis.

\begin{tabular}{|c|c|}
\hline Samples & Generated $\mathrm{O}_{2}^{-}\left(\times 10^{-5} \mathrm{mmol} / \mathrm{ml}\right)$ \\
\hline Agaricus burazei & 2.64 \\
\hline Chlorella pirenoidosa & 1.95 \\
\hline SDT & 1.24 \\
\hline BYT & 1.25 \\
\hline sCRT & 2.88 \\
\hline Propolis & 2.55 \\
\hline Control & 2.85 \\
\hline
\end{tabular}

Table 3. Constitution dependent effect on human monocyte.

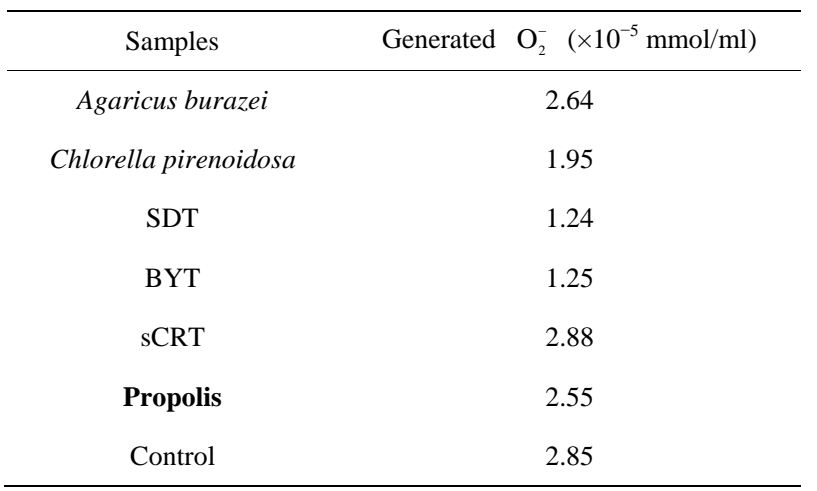

is reported to cause many disorders such as cancer, ischemic heart disease and diabetes [18-20]. Although there are many reports in which the newly found antioxidants were reported and discussed about the molecular mechanism of how oxidative stress damage the human tissue [26-36], few experiments have been done in vivo which could reflex more precisely the biological response.

The purpose of this study has been to establish the method which is useful for evaluating the activity of antioxidant ex vivo. As shown above, in our experiment design the amount of super oxide anion generation decreased significantly after one week administration of some drugs. The advantage of this method might be the amount of super oxide anion generation could express clearly in concrete numeral, so it makes easy to compare various drugs.

The most interesting in this assay was that the genera- 
tion of super oxide anion was much inhibited after white wine administration than red wine. It is widely accepted that polyphenol contained in red wine has great antioxidative effect. However, as we demonstrated in this report, white wine has more efficient anti-oxidative activity. The confusion such as red wine has brilliant super oxide anion scavenge effect might be caused by the reports in which in vitro examined polyphenol's antioxidative activity was discussed. Thus, we would like to suggest to test the anti-oxidative activity, if possible, in vivo in future.

In this report, the method how to measure the amount of super oxide anion generation when drugs were administered ex vivo was shown. Using this method, it would make easy to test the anti-oxidantive activity of any drugs and supplements. Here we just demonstrated the antioxidants, Agaricus, Chrollera, three Shi-Quan-DaBu-Tang (SDT), Bu-Zong-Ye-Qi-Tang (BYT) and ShaoChin-Rong-Tang (sCRT), and Propolis. We hope other proposed drugs and supplements would also be tested objectively its antioxidative effects and an appropriate information about antioxidants would be reported.

Human subject. As the same in case of murine macrophage, fermented TCM were effective to regulate super oxide anion. Furthermore, G-type was much regulated anti oxidative effect than L-type of monocyte, indicting neat regulation for different constitution [37-40]. This will be brought the difference of oxidative activity in monocyte in human blood, as qualitative aspect. The anti-oxidative stress regulated as armed forces reduction treaty but not dissemination of armed forces.

\section{REFERENCES}

[1] S. Gorantla, H. Dou, M. Boska, C. J. Destache, J. Nelson, L. Poluektova, B. E. Rabinow, H. E. Gendelman and R. L. Mosley, "Quantitative Magnetic Resonance and SPECT Imaging for Macrophage Tissue Migration and Nanoformulated Drug Delivery," Journal of Leukocyte Biology, Vol. 80, No. 5, 2006, pp. 1165-1174. http://dx.doi.org/10.1189/jlb.0206110

[2] R. S. Stoika, M. D. Lutsik, M. L. Barska, A. A. Tsyrulnyk and N. I. Kashchak, "In Vitro Studies of Activation of Phagocytic Cells by Bioactive Peptides," Journal of Physiology and Pharmacology, Vol. 53, No. 4, 2002, pp. 675-688.

[3] C. Elbim, S. Pillet, M. H. Prevost, A. Preira, P. M. Girard, N. Rogine, J. Hakim, N. Israel and M. A. Gougerot-Pocidalo, "The Role of Phagocytes in HIV-Related Oxidative Stress," Journal of Clinical Virology, Vol. 20, No. 3, 2001, pp. 99-109. http://dx.doi.org/10.1016/S1386-6532(00)00133-5

[4] C. P. Speer, M. Gahr and M. J. Pabst, "PhagocytosisAssociated Oxidative Metabolism in Human Milk Macrophages,” Acta Paediatrica Scandinavica, Vol. 75, No. 3, 1986, pp. 444-451.

http://dx.doi.org/10.1111/j.1651-2227.1986.tb10228.x
[5] C. Elbim, S. Pillet, M. H. Prevost, A. Preira, P. M. Girard, N. Rogine, J. Hakim, N. Israel and M. A. Gougerot-Pocidalo, "The Role of Phagocytes in HIV-Related Oxidative Stress,” Journal of Clinical Virology, Vol. 20, No. 3, 2001, pp. 99-109. http://dx.doi.org/10.1016/S1386-6532(00)00133-5

[6] D. L. Waitzberg, R. Bellinati-Pires, M. M. Salgado, I. P. Hypolito, G. M. Colleto, O. Yagi, E. M. Yamamuro, J. Gama-Rodrigues and H. W. Pinotti, "Effect of Total Parenteral Nutrition with Different Lipid Emulsions of $\mathrm{Hu}-$ man Monocyte and Neutrophil Functions,” Nutrition, Vol. 13, No. 2, 1997, pp. 128-132. http://dx.doi.org/10.1016/S0899-9007(96)00386-3

[7] S. S. Kaplan, R. E. Basford, M. H. Jeong and R. L. Simmons, "Biomaterial-Neutrophil Interactions: Dysregulation of Oxidative Functions of Fresh Neutrophils Induced by Prior Neutrophil-Biomaterial Interaction,” Journal of Biomedical Materials Research, Vol. 30, No. 1, 1996, pp. 67-75.

http://dx.doi.org/10.1002/(SICI)1097-4636(199601)30:1< 67::AID-JBM9>3.0.CO;2-P

[8] M. S. Cohen, B. E. Britigan, Y. S. Chai, S. Pou, T. L. Roeder and G. M. Rosen, "Phagocyte-Derived Free Radicals Stimulated by Ingestion of Iron-Rich Staphylococcus aureus: A Spin-Trapping Study,” Journal of Infectious Diseases, Vol. 163, No. 4, 1991, pp. 819-824. http://dx.doi.org/10.1093/infdis/163.4.819

[9] J. L. Mege, C. Martin, P. Saux, J. Charrel, M. N. Mallet and P. Bongrand, "Phagocyte-Pathogen in the Infected Host,” Critical Care Medicine, Vol. 17, No. 12, 1989, pp. 1247-1253.

[10] C. P. Speer, M. Gahr and M. J. Pabst, "PhagocytosisAssociated Oxidative Metabolism in Human Milk Macrophages,” Acta Paediatrica Scandinavica, Vol. 75, No. 3, 1986, pp. 444-451. http://dx.doi.org/10.1111/j.1651-2227.1986.tb10228.x

[11] R. K. Root, A. S. Rosenthal and D. J. Balestra, “Abnormal Bactericidal, Metabolic, and Lysosomal Functions of Chediak-Higashi Syndrome Leukocytes,” Journal of Clinical Investigation, Vol. 51, No. 3, 1972, pp. 649-665. http://dx.doi.org/10.1172/JCI106854

[12] L. J. Ignarro and C. Colombo, "Enzyme Release from Polymorphonuclear Leukocyte Lysosomes: Regulation by Autonomic Drugs and Cyclic Nucleotides," Science, Vol. 180, No. 4091, 1973, pp. 1181-1183. http://dx.doi.org/10.1126/science.180.4091.1181

[13] B. H. Dulis and I. B. Wilson, "The $\beta$-Adrenergic Receptor of Live Human Polymorphonuclear Leukocytes,” Journal of Biological Chemistry, Vol. 255, 1980, pp. 1043-1048.

[14] H. Nakahata, M. Tsujino, Y. Hirai, Y. Kumasaka, T. Nakamura, T. Onuma M. Kudo, K. Takebe and H. Kudo, "Clinical Study of Superoxide Disumutase (SOD) in NIDDM-Serum and Polymorphonuclear Leukocyte (PMN) SOD Activity by Nitrite Method," Journal of the Japan Diabetes Society, Vol. 33, No. 12, 1990, pp. 965971.

[15] M. Iqbal, S.-D. Sharma, Y. Okazaki, M. Fujisawa and S. Okada, "Dietary Supplementation of Curcumin Enhances Antioxidant and Phase II Metabolizing Enzymes in ddY Male Mice; Possible Role in Protection against Chemical 
Carcinogenesis and Toxicity," Pharmacology \& Toxicology, Vol. 92, No. 1, 2003, pp. 33-38.

http://dx.doi.org/10.1034/j.1600-0773.2003.920106.x

[16] H. Kohno, T. Tanaka, K. Kawabata, Y. Hirose, S. Sugi, H. Tsuba and H. Mori, "Silymarin, a Naturally Occurring Polyphenolic Anotioxidant Flavionoid, Inhibits Azoxymethane-Inbuced Colon Carcinogenesis in Male F344 Rats," International Journal of Cancer, Vol. 101, No. 5, 2002, p. 4618. http://dx.doi.org/10.1002/ijc.10625

[17] M. Karbownik, D. Tan, L.-C. Manchester and R.-J. Reiter, "Renal Toxicity of the Carcinogen Delta-Aminolevulinic Acid: Antioxidant Effects of Melatonin,” Cancer Letters, Vol. 161, No. 1, 2000, pp. 1-7.

http://dx.doi.org/10.1016/S0304-3835(00)00568-1

[18] D. Harman, “Aging: A Theory Based on Free Radical and Radiation Chemistry," Journal of Gerontology, Vol. 11, No. 3, 1956, pp. 293-300. http://dx.doi.org/10.1093/geronj/11.3.298

[19] M. Inoue, "Free Radical Theory of Aging," Nippon Ronen Igakkai Zasshi, Vol. 39, No. 1, 2002, pp. 36-38. http://dx.doi.org/10.3143/geriatrics.39.36

[20] H.-K. Biesalski, "Free Radical Theory of Aging," Current Opinion in Clinical Nutrition and Metabolic Care, Vol. 5, No. 1, 2002, pp. 5-10. http://dx.doi.org/10.1097/00075197-200201000-00002

[21] Y.-H. Wei and H.-C. Lee, “Oxidative Stress, Mitochondrial DNA Mutation, and Impairment of Antioxidant Enzymes in Aging," Experimental Biology and Medicine (Maywood), Vol. 227, No. 9, 2002, pp. 671-682.

[22] N. Sanz, C. Diez-Fernandez, D. Andres and M. Cascales, "Hepatotoxicity and Aging: Endogenous Antioxidant Systems in Hepatocytes from 2-, 6-, 12-, 18- and 30Month-Old Rats Following a Necrogenic Dose of Thioacetamide," Biochimica et Biophysica Acta, Vol. 1587, No. 1, 2002, pp. 12-20. http://dx.doi.org/10.1016/S0925-4439(02)00048-0

[23] J. Diamond, J. Skaggs and J.-M. Manaligod, "Free-Radical Damage: A Possible Mechanism of Laryngeal Aging," Ear, Nose \& Throat, Vol. 81, No. 8, 2002, pp. 531-533.

[24] S. Melov, “Animal Models of Oxidative Stress, Aging, and Therapeutic Antioxidant Interventions," International Journal of Biochemistry \& Cell Biology, Vol. 34, No. 11, 2002, pp. 1395-1400. http://dx.doi.org/10.1016/S1357-2725(02)00086-9

[25] P.-J. Arockia-Rani and C. Panneerselvam, "Carnitine as a Free Radical Scavenger in Aging,” Experimental Gerontology, Vol. 36, No. 10, 2001, pp. 1713-1726. http://dx.doi.org/10.1016/S0531-5565(01)00116-4

[26] M, Kasapoglu and T. Ozben, "Alterations of Antioxidant Enzymes and Oxidative Stress Markers in Aging," Experimental Gerontology, Vol. 36, No. 2, 2001, pp. 209-220. http://dx.doi.org/10.1016/S0531-5565(00)00198-4

[27] J.-P. Perchellet and M. Perchellet, “Antioxidants and Multistage Carcingenesis in Mouse Skin,” Free Radical Biology and Medicine (Medsci), Vol. 7, No. 4, 1989, pp. 377-408. http://dx.doi.org/10.1016/0891-5849(89)90124-X

[28] F. Edsmyr, "Super Oxide Anion Dismutase Efficacy in
Ameliorating Side Effects of Radiation Therapy,” In: A. M. Autor, Ed., Pathology of Oxygen, Academic Press, New York, 1982, pp. 315-326.

[29] M. H. Johansson, J. Deinum, S. L. Marklund and P.-O. Sjoquist, "Recombinant Human Extra-Celluar Super Oxide Anion Dismutase Reduces Concentration of Oxygen Free Redicals in the Reperfusedret Heart," Cardiouas, Vol. 24, 1990, pp. 500-503.

[30] S. K. Venugopal, S. Devaraj, T. Yang and L. Jialal, “Alpha-Tocopherol Decreases Superoxide Anion Release in Human Monocytes under Hyperglycemic Conditions via Inhibition of Protein Kinase C-Alpha,” Diabetes, Vol. 51, No. 10, 2002, pp. 3049-3054.

http://dx.doi.org/10.2337/diabetes.51.10.3049

[31] D. U. Nayak, C. Karmen, W. H. Frishman and B. A. Vakili, "Antioxidant Vitamins and Enzymatic and Synthetic Oxygen-Derived Free Radical Scavengers in the Prevention and Treatment of Cardiovascular Disease," Heart Disease, Vol. 3, No. 1, 2001, pp. 28-45. http://dx.doi.org/10.1097/00132580-200101000-00006

[32] Y. Miyachi, "Skin Diseases Associated with Oxidative Injury,” In: J. Fuchs and L. Packer, Eds., Oxidative Stress in Dermatology, Marcel Dekker, New York, 1993, pp. 323-331.

[33] D. De-Beer, E. Joubert, W.-C. Gelderblom and M. Manley, "Antioxidant Activity of South African Red and White Cultivar Wines: Free Radical Scavenging," Journal of Agricultural and Food Chemistry, Vol. 51, No. 4, 2003, pp. 902-909. http://dx.doi.org/10.1021/jf0260110

[34] S.-E. Lee, E.-M. Ju and J.-H. Kim, "Free Radical Scavenging and Antioxidant Enzyme Fortifying Activities of Extracts from Smilax China Root,” Experimental and Molecular Medicine, Vol. 33, No. 4, 2001, pp. 263-268. http://dx.doi.org/10.1038/emm.2001.43

[35] R. Joshi, S. Adhikari, B.-S. Patro, S. Chattopadhyay and T. Mukherjee, "Free Radical Scavenging Behavior of Folic Acid: Evidence for Possible Antioxidant Activity,” Free Radical Biology \& Medicine, Vol. 30, No. 12, 2001, pp. 1390-1399. http://dx.doi.org/10.1016/S0891-5849(01)00543-3

[36] C.-C. Lin, Y.-F. Hsu and T.-C. Lin, "Antioxidant and Free Radical Scavenging Effects of the Tannins of Terminalia catappa L.,” Anticancer Research, Vol. 21, No. 1A, 2001, pp. 237-243.

[37] T. Abo and T. Kumagai, "Studies of Surface Immunoglobulins on Human B Lymphocytes. Physiological Variations of Sig ${ }^{+}$Cells in Peripheral Blood," Clinical Experimental Immunology, Vol. 33, No. 3, 1978, pp. 441-452.

[38] V. M. Sanders, R. A. Baker, D. S. Ramer-Quinn, D. J. Kasprowicz, B. A. Fuchs and N. E. Street, "Differential Expression of the $\beta_{2}$-Adrenaergic Receptor by Th1 and Th2 Clones," Journal of Immunology, Vol. 158, 1997, pp. 4200-4210.

[39] T. Abo, T. Kawate, K. Itoh and K. Kumagai, "Studies on the Bioperiodicity of the Immune Response. 1. Circadian Rhythms of Human T, B and K Cell Traffic in the Peripheral Blood,” Journal of Immunology, Vol. 126, No. 4, 1981, pp. 1360-1363.

[40] Y. Kitada, K. Okamoto, T. Takei, X. F. Jia, R. Chen, N. 
Yamaguchi, M. Tsubokawa, W. H. Wu, T. Murayama and K. Kawakita, "Hot Spring Hydro Therapy Regulate Peripheral Leukocyte Together with Emotional Hormone and Receptor Positive Lymphocytes According to Each

\section{Abbreviations}

BYT: Bu-Zong-Ye-Qi-Tang; A famous TCM decoction for augment blood cell in quantitatively and qualitatively. CAM: complementary and alternative medicine, beside the western medicine, there are many traditional medicine and/or health promoting menu all over the world.

CD: Cluster of differentiation. Each lymphocyte has name that expressed CD number, for example CD2, CD4, CD8 etc.

G-rich type: The individual that exhibit over $60 \%$ of granulocyte in peripheral blood, finding many in young gentleman.
Constitution/Condition," Open Journal of Rheumatology and Autoimmune Diseases, Vol. 3, No. 3, 2013, pp. 140153. http://dx.doi.org/10.4236/ojra.2013.33022

L-rich type: The individual that exhibit over $40 \%$ of lymphocyte in peripheral blood, finding lot in ladies and senile.

TCM: traditional chinese medicine.

QOL: Quality of life.

SOD: super oxide dismutase.

SDT: Shi-Quan-Da-Bu-Tang; A famous TCM decoction for augment blood cell in quantitatively and qualitatively. sCRT: Sao-Chin-Rong-Tang; A famous TCM decoction for regulate inflammation such as allergic reaction in nose, eye and dermato site. 